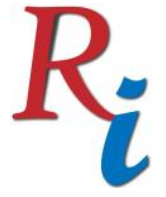

Asia Proceedings of Social Sciences

(APSS)

www.readersinsight.net/APSS

\title{
Toward SMEs Engagement in Improving Creative Economic in Indonesia
}

\section{Hendry Hartono*}

Management Department, BINUS Business School Undergraduate Program, Universitas Bina Nusantara, Indonesia

\section{Ruby Dary Haniya}

Management Department, BINUS Business School Undergraduate Program, Universitas Bina Nusantara, Indonesia

*Corrosponding author's Email: hhartono@binus.edu

Peer-review under responsibility of $4^{\text {th }}$ Asia International Conference 2018 editorial board

(http://www.utm.my/asia/our-team/)

(C) 2018 Published by Readers Insight Publisher, lat 306 Savoy Residencia, Block 3 F11/1,44000 Islamabad. Pakistan, info@ readersinsight.net

This is an open access article under the CC BY-NC-ND license (http://creativecommons.org/licenses/by-nc-nd/4.0/). 


\section{Research High Iight s}

The stusy proposed three hyphothesis and results indicates that capacity building has no significant influence toward SMEs engagement. Meanwhile, service quality has a significant influence on SMEs engagement. Based on multiple regression calibration shows capacity building and service quality has a significant influence on SMEs engagement. Integrated Business Service Center for Cooperatives and Micro, Small and Medium Enterprises (PLUTKUMKM) should provide periodicaly trainings or seminars to entrepreneurs to increase their capability facing the competition more confidence and as an institution should provide celar information about the function and their services for developing SMEs in Indonesia.

\section{Research Objectives}

Entrepreneur plays an important role in the structure of the economy, where the entrepreneur dominate business sector by $99.9 \%$ an also absorb almost $97 \%$ workforce in Indonesia. New entrepreneur increases annually by more than $20 \%$, for this matter Indonesian government excited to develop and empower the entrepreneur so can have capability to compete within other business in the other regions. Ministry of Cooperatives and SMEs to create programs to improve the quality of SMEs, namely by establishing an Integrated Business Service Center for Cooperatives and Micro, Small and Medium Enterprises (PLUT-KUMKM). The purpose of this research is to know the influence of capacity building and service quality of PLUTKUMKM towards SMEs engagement in improving creative economy in Indonesia.

\section{Methodology}

The unit of analysis is determined by using simple random sampling technique to the SMEs fostered by PLUT-KUMKM. The unit of observation is determined by the business actor / entrepreneur of the SMEs. By the Slovin sampling technique with the confidence level of $95 \%$ the size of unit of analysis is determined to be 110 SMEs. The purpose of this study to determine the causal relationship between two or more variables and the level of dependence 


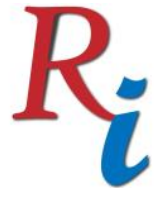

\section{Asia Proceedings of Social Sciences \\ (APSS) \\ www.readersinsight.net/APSS}

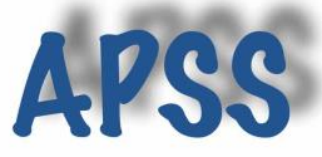

between these variables. Time Horizon used by writer is cross sectional. In associative research used to analyze Capacity Building (X1) and Service Quality (X2) to SME Engagement (Y) in Subang Regency. In measuring the answers of questionnaires submitted to the respondents, the scale used is 5 Scale Likert. The method of analysis used is descriptive statistics, simple regression, and multiple regression. This research is done by using statistical software SPSS 22. Before analyzing further, the validity and reliability of the instruments has been done. The validity items of the instruments are above 0.5 for acceptable validity instrument (Hair et al., 2009) and with the value higher than commonly used threshold for acceptable reliability of 0.7 , with Cronbach's alpha ranged from 0.809 to 0.940 .

\section{Results}

110 respondents surveyed, and dominated by female entrepreneurs (58\%) and the dominant entrepreneurs are between the ages of 26 and 35. As mature ages (26-35), shows a balance between preparation to start a business, a sense of responsibility in running a business and obligations to the family (Meliala et al., 2014). Based on educational background, more dominated by high school education background and they tend to choose food and beverage business with income below 5 Million Rupiahs (37\%). Capacity building does not significantly affect SMEs engagement in improving economic creative in Indonesia, but service quality gives a significant influence to SMEs engagement.

\section{Findings}

Capacity building has no significant effect on SMEs engagement. Meanwhile, service quality has a significant effect on SMEs engagement so that PLUT-KUMKM should provide training or seminars evenly to all SMEs in order to improve the ability and capacity of business actors so that competitiveness and also improving enthusiasm of entrepreneurs in running their business. Information provided to SMEs should be clear about the function of PLUTKUMKM as an institution that provides services to consult the business and give assistance for further development of their business. Based on the existing literature and qualitative interviews in this research, we have proposed an antecedent framework for successful SMEs engagement. Future research needed to explore engagement strategy, condition of facilitating 


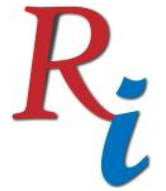

\section{Asia Proceedings of Social Sciences \\ (APSS) \\ www.readersinsight.net/APSS}

environment, also exploration regarding interaction between local government commitment and SMEs condition(Gualini, 2017; Lya, 2018; Rhee Seung-Kyu and Rha, 2009).

\section{Acknowledgement}

Authors would like to thank all of the entrepreneurs in Indonesia who are willing to taking part during online and offline questionnaires and also like to thanks to Universitas Bina Nusantara for the fully support and providing fund so that this research paper can be done.

\section{References}

Gualini, E., 2017. Institutional capacity building as an issue of collective action and institutionalisation: Some theoretical remarks, in: Urban Governance, Institutional Capacity and Social Milieux. pp. 29-44. https://doi.org/10.4324/9781315202877

Hair, J.., Black, W.D., J., B.B., Anderson, R.E., 2009. Multivariate data analysis, Maritime Policy \& Management. https://doi.org/10.1007/978-94-009-3789-5

Lya, Y., 2018. PERANAN PUSAT LAYANAN USAHA TERPADU KOPERASI USAHA MIKRO KECIL DAN MENENGAH (PLUT-KUMKM) DALAM PEMBERDAYAAN USAHA MIKRO.

Meliala, A.S., Matondang, N., Sari, R.M., 2014. Strategi Peningkatan Daya Saing Usaha Kecil dan Menengah (UKM) Berbasis Kaizen. J. Optimasi Sist. Ind. 13 (2), 641-664.

Rhee Seung-Kyu, S.K., Rha, J.Y., 2009. Public service quality and customer satisfaction: Exploring the attributes of service quality in the public sector. Serv. Ind. J. 29, 1491-1512. https://doi.org/10.1080/02642060902793441 